\title{
Opinions of Instructors Related to the Physical Layout Dimension of Virtual Classroom Management
}

\author{
Seçil Kaya, Esmahan Ağaoğlu \\ Anadolu University, Turkey
}

\begin{abstract}
Face to face and virtual classrooms that came up with different conditions and environments; but for similar purposes have different characteristics in terms of the media and the rules observed. Today, virtual learning wrap into a comprehensive model because of its mass advantages related to educational opportunities. On the other hand, using virtual classrooms in advantageous and effective way has a close relationship with successful classroom management. In this context, physical layout as one of the most important distinguishing features of virtual and face-to-face classes should be examined in detail. Another determinative issue that effects the effective management of classroom is the roles and opinions of the instructors. So it can be said that opinions of instructors related to the physical layout of virtual classes can be associated with effective management. In this study, opinions and perceptions of the teaching staff related to the physical dimensions of classroom management were determined by using qualitative and quantitative research techniques. Within the qualitative techniques focus group interview was used. On the other hand quantitative data was collected through a questionnaire, which was developed by the researchers. Analysis of the data was presented as frequencies and percentages for each item. Analysis were obtained and interpreted in relation with the qualitative data provided by focus group.
\end{abstract}

\section{Introduction}

Computer and Internet is one of the most important implications of new technologies in the field of education. The use of the Internet as learning and teaching tool is increasing all over the world [1]. If computers, Internet, communication technologies and education will be considered together, some different approaches like virtual classrooms comes into question as an alternative to traditional schools and classrooms that focused on the physical space.

Virtual classrooms in which traditional teaching methods are offered through non-traditional media have some special requirements [2]. They have some similar facilities with face-to-face classes such as program, students and administrators. But in virtual classes that have no walls and corridors, students can attend the courses from a distance and can control their own learning spaces [3].

Rutkowski [4] focuses on the issue that virtual schools began to challenge the formal traditional schools. However, virtual educational institutions that offer training facilities to huge populations should be differentiate in many ways. The development of effective virtual applications requires reexamining some dimensions like success, validation, management, educational, psychological, and social dynamics. Thus, it will be possible to produce different and functional models for virtual learning.

To achieve educational goals within the scope of distance education and virtual classes, successful classroom management as the first step of successful education plays a critical role as well as the face-to-face classes.

In this context, when we look at the formal face-to-face classroom management, it is discussed in five dimensions including physical layout, plan \& program activities, behavior management, time management, and opportunities for interaction [5] [6]. Firstly, each of these dimensions needs to be addressed in terms of virtual education. In addition to these dimensions, it is thought that there should be one more dimension for virtual classrooms as technology management.

Considering the scope of the virtual classroom management dimensions, the physical layout as one of the main dimensions of classroom management; as well as one of the most important distinguishing features of virtual and face-to-face classes is an important feature that affects the educators' attitudes and behaviors. So it is thought that a comparative description of physical layout will be helpful for the instructors. 


\section{Differentiating Physical Layout Characteristics for Face-to-Face and Virtual Classroom Management}

The physical layout of classroom indicates the media, features and class-equipment that are devoted to teaching-learning process [7]. For effective classroom management, physical variables should be regulated in instructive, engaging and motivational format [8]. Arrangements in educational settings affect the student motivation, continuity of attention and the quality of the teacher-student relationship.

Physical layout variables in the classroom are number of students, placement arrangements, heatlight-color, blank spaces, noise, cleanliness and appearance elements [7] [9] [10] [11]. However, the physical layout of face-to-face classes and virtual classes in which students and educators are located in different places differ from each other [12].

Number of students as one of the sub-topics of physical layout, is a common characteristic for both face-to-face and virtual classes; but it is remarkable that the elements taken into account to determine the number of students differs for each case. It won't be a realistic approach to set rules about the number of students that are accepted in every case. However, in both cases crowded classes are not preferred. If the class is not crowded, teaching method can diversify, educators may allow more time for each student, student development can be monitored easily and class can be managed more effectively [13]. Also there are some characteristics that affect the decision related number of students for effective classroom management. These characteristics are educational level, type of course, subject area and the methodology. In terms of virtual classrooms, students' and instructors' information and communication technology usage skills are also taken into account in addition to all of these elements. Number of students isn't regarded as a problem for asynchronous applications of virtual classrooms and this is considered as an advantage of online courses when compared with face-to-face classes. But synchronous communication activities are slightly different.

Synchronous communication activities in which students contact with other students and teachers at the same time but from different places, there are some control mechanisms and limitations in similar with the face-to-face classes. Designs that allow students to communicate only when the instructor let them talk or the online applications that enable students to raise their hand is one of the control mechanisms in virtual classes. With these control mechanisms, without the consent of the instructor, speaking students cannot be heard by other students. "Noise" caused by students who are speaking without the permission of instructor in face-to-face classes can be prevented in this way within the virtual classrooms. On the other hand, two-way communication between instructor and student can be provided with custom dialog windows in virtual classrooms. This two-way communication processes can be performed without disrupting the educational process or the attention of other students. Therefore, the problems caused by the excess number of students can be kept under control or minimized.

On the other hand, the intensity of the written messages in virtual classrooms can cause problems in terms of reading and understanding. Also it can be difficult for educators to answer all messages [14]. At this point, using different colors in written texts come to the agenda; but at this time the diversity of colors causes a visual pollution that can lead to dissolution on the attention of the students. Using different color, font or font size for written messages only by the instructor can be considered as a solution for the problems related to written follow-up messages.

Although the class size is considered to be another influential factor in determining the number of students in face-to-face classes, it isn't determinative for distance learning and virtual classrooms. Students' cognitive and emotional development, course methods, subject area, technology and the frequency of interaction are considered to be more determinative and influential in determining the number of students for virtual classrooms.

The technology is also an important feature in terms of the elements of the noise encountered in the process of education. Technological problems like crackling, too high or too low sound, internet connection problems or lack of hardware may cause disruptions or delays in teaching-learning process. Therefore, the technological infrastructure is considered to be an important feature for virtual classroom to avoid the noise problems.

The placement arrangements dimension of classroom management is another feature taken up under the heading of "physical layout". A successful placement has a positive impact on teaching, classroom interaction, and facilitates to access the resources [8]. Virtual classrooms, that eliminate the physical boundaries, don't require any arrangements in terms of placement. All 
students join the course by their individual computers; so there is a virtual togetherness in virtual classrooms. In virtual classrooms students are always at the forefront of the class and messages from the educator directly reaches to the students. This facilitates that the students feel special and concentrate more easily [14].

Features that are taken into account for placement arrangements like length, sight, hearing, gender and so on lose their validity in virtual classrooms. On the other hand, arrangements of the course tools and materials in easily visible and audible way can be considered within the context of instructional design.

In virtual classrooms, the layout of instructor is as important as the students'. The educator must have the necessary equipment and be away from external noise sources to control the learning process effectively. In this manner, they can follow the heavy written messages, be able to transfer educational content effectively and keep the students' attention awake. Being a crowded office environment or constantly ringing phones will lead to disruptions and breaks in teaching process. These disruptions as a noise factor will directly affect the students' motivation and learning process; so have more negative effects then disruptions of students.

Another feature which is covered by the physical layout is "heat, light, color, noise and cleanliness". The color is an effective factor on human psychology [8]. On the other hand, hotter, colder and dirtier classes can have negative impacts on both students' and instructors' motivation; so it can increase the effectiveness of the educational process. It is not possible to talk about "heat, light, color, noise and cleanliness" for virtual classrooms that have no walls, pulpit, seating and any other tangible elements. Therefore, these features can be considered as visual design components within the virtual classrooms.

The visual design or the virtual interface design is related with the appearance and ease of use of the platform used within the virtual classrooms. In this context, use of colors, texts, blank spaces, lines, graphics or animations can be handled as virtual elements. Using appropriate font, line, paragraph spacing and compelling graphics, writing understandable statements is also important for the design of virtual classrooms. So the cleanliness of virtual classrooms can be considered as the concept of visual simplicity. We can say that designing an interface that the content can easily be placed is very important for the virtual classroom.

On the other hand, archives, bibliographies, ebooks, links, glossary, units, course summaries and example studies that students can access when they $\log$ in their classes are considered as the support materials for virtual classes.

\section{Problem}

Management dimensions of virtual classrooms were tried to determine in accordance with habits of face-to-face education in many countries. However, if the standards are shaped in accordance with face-to-face education habits, virtual classrooms cannot provide the expected benefits and desired efficiency.

On the other hand, it isn't a realistic approach to think that all the instructors have the ability to conduct lessons in a virtual environment. Face-toface teaching experience doesn't mean that they will be successful in the management of virtual classrooms. They may need different management skills in addition to knowledge and interest for using educational technology [15].

On the other hand, preferred learning styles have changed from oral to images, and finally to virtual. This change brings up a new question: "How can the youth of today that are accepted as virtual generation or next generation be educated in the best way?" To determine the most suitable learning styles for the virtual generation, educators focused on the new media that focuses on the electronic learning environments. To achieve desired results within the virtual classes, primarily learning principles and dynamics that can increase the effectiveness of these technologies should be understood and taken into account in the regulation of virtual learning environments [16]. Also it should be noted that, although technology plays an important role in the solution of educational problems and make new generation keeps up with the times; technology is inadequate alone. For effective use of educational technology, teaching staff qualifications and responsibilities are also determinative.

For effective management, it is thought that determining the educators' perceptions and skills about the management dimensions of virtual classes is necessary. In this context, it was aimed to determine the teaching staff's perceptions about the physical layout dimension of virtual classroom management. Thus, similarities and differences of face-to-face and virtual classes related to the physical layout dimension can be found out. 


\section{Methodology}

Within this research, both qualitative and quantitative research techniques were used. "Physical layout" dimension of a comprehensive questionnaire that aims to identify the educational needs of instructors for effective virtual classroom management was used. Questionnaire, which was developed by the researcher and got its final form in accordance with the expert opinions, was used to put forward views of teaching staff.

Questionnaire was transferred to the electronic platform and delivered to the instructors via their email addresses. Anadolu University survey server was used to transfer the questionnaire in the electronic platform. The implementation process was completed over a period of approximately 4.5 months.

The data obtained from the "physical layout" dimension of the questionnaire were analyzed with quantitative research techniques. Analysis of the data was presented as frequencies and percentages for each item. On the other hand, these quantitative analyses were interpreted in relation with the qualitative data provided by focus group. Focus group interview as a qualitative research technique was realized with the participation of 7 instructors.

\section{Population and Sample Group}

Population of the study is the teaching staff who were experienced in managing virtual classes within the Turkish Higher Education System. In this context, 480 educators from 12 universities are determined as the accessible population. The minimum sample size was calculated as 214 to represent the population. But it is considered that there can be some problems about the return of the questionnaires. So the questionnaire has delivered to 480 faculty members and 228 questionnaires have returned.

Answers for "what should the number of students be for effective management of virtual classes?" were examined and it was seen that the appropriate number of students was mentioned as over 100. It means that the concept of the virtual classroom was detected in different way (asynchronous web-based courses) in these 4 questionnaires. On the other hand, it is determined that 9 questionnaires were incomplete. So 13 questionnaires were considered as invalid at the end of the control process. Finally, 215 questionnaires were taken into consideration within the analyses.
Table 1. Personal Information of Sample Group

\begin{tabular}{llrr}
\hline \multirow{2}{*}{ Experience } & & f & \% \\
\hline \multirow{2}{*}{ Gender } & 1-4 Semesters & 127 & 59 \\
\cline { 2 - 4 } & More than 5 semesters & 88 & 41 \\
\hline \multirow{2}{*}{ Title } & Female & 89 & 41,4 \\
\cline { 2 - 4 } & Male & 126 & 58,6 \\
\cline { 2 - 4 } & Lecturer & 96 & 44,7 \\
\cline { 2 - 4 } & Lecturer, PhD. & 19 & 8,80 \\
\cline { 2 - 4 } & Assistant Professor, PhD. & 55 & 25,6 \\
\cline { 2 - 4 } & Associate Professor, PhD. & 28 & 13,0 \\
\cline { 2 - 4 } In-service Training & Professor, PhD. & 17 & 7,90 \\
\cline { 2 - 4 } & Yes & 114 & 53,0 \\
\cline { 2 - 4 } & No & & \\
\hline
\end{tabular}

As seen in Table 1, it is determined that $59 \%$ of the sample group has experience in virtual classes between $1-4$ semesters. Also $41 \%$ of the teaching staff was managing virtual classes more than 5 semesters. Majority of the sample group is titled as Lecturer with $53,5 \%$ and professors have the minimum percentage with $7,9 \%$. On the other hand, percentages related to the in-service training status are very close to each other. $47 \%$ of them had an in-service training before assigned within the virtual classes.

When the participants of focus group are examined, totally 7 teaching staff were participated which 3 of them was experienced in only managing virtual classes and 4 of them were experienced in both designing and managing the virtual classes.

\section{Findings}

When the findings relevant to the physical layout of virtual classrooms were examined, primarily participants were asked for their general views related to the physical layout of virtual classrooms within the focus group interview. Related to the adoption of physical layout dimension to the virtual classrooms, one of the focus group participants (P4) mentioned that:

(P4) "'The new trend in virtual classes is as follows: Instructor provides and presents a template for the students. However, students can change this template in accordance with their habits. For example, the user list is on the left, the text is on the right and at the bottom they can see the tests related to the subject. Students can change the placements of these areas according to their preferences. Providing such options that student can change them easily can be considered as physical layout of virtual classrooms. I think it's the most reasonable thing anyway. Most of the virtual classroom application supports it. " 
(P4) "Normal seating positions in face-to-face classes can be considered as our students list in virtual classes. Students work on tables in regular classrooms. In virtual classrooms, textbased messaging area is our table. In this context, handling table as the text-based messaging overlaps with formal face-to-face classes. Also in virtual classrooms, students attended courses from their homes as relaxed learning environment"

After the general views, the number of students, noise and design elements are the main features that are discussed within the scope of the physical layout of virtual classrooms. If the number of students is discussed firstly, answers related to the optimum number of students for effective management of virtual classes are given in Table 2 .

\section{Table 2. Optimum Number of Students}

\begin{tabular}{rrrr}
\hline & & f & \% \\
\hline Valid & $4-15$ & 125 & 58,2 \\
\cline { 2 - 4 } & $16-30$ & 85 & 39,4 \\
\cline { 2 - 4 } & $30-35$ & 5 & 2,4 \\
\hline Total & $\mathbf{2 1 5}$ & $\mathbf{1 0 0 , 0}$ \\
\hline
\end{tabular}

As seen in Table 2, \%58,2 of the participants mentioned that number of students should be up to 15 and $39,4 \%$ of them thought that number of students could change from 15 to 30 . Only $2,4 \%$ of the participants mentioned that number of students could be more than 30 . Related to the number of students, the common opinions of P1, P2 and P3 as the participants of the focus group can be stated as below:

(P1-P2-P3) "15 students are even more for virtual classrooms. The optimum number should be 7-10. Smaller groups mean less problems and more effective teaching."

When the correlation between the findings of focus group and questionnaire is considered, it can be said that both focus group and questionnaire findings emphasis on the necessity of keeping the number of students as low as possible.

On the other hand, although it is mentioned that the number of students should be up to 15 according to the focus group participants, it is increased up to 35 within the survey results. According to survey data, most of the participants $(41.6 \%)$ believe that the number of students can be increased up to 35 . This situation can be associated with the characteristics, possibilities and limitations of Turkish Higher Education System. Limitations like the lack of enough trained and experienced teaching staff about virtual classes prevent the spread of virtual classrooms and to teach in more crowded classes. However, virtual classrooms are increasingly common day by day and become more widespread; so it can be said that the ideal number and characteristics can be achieved by time.

The features that are taken into account in determining the number of students in virtual classrooms and the responses to the relevant features are given in Table 2.

\section{Table 3. Features Taken into Account in Determining the Number of Students}

\begin{tabular}{lcccc}
\hline & \multicolumn{2}{c}{ Y } & \multicolumn{2}{c}{ N } \\
\hline & f & \% & f & \% \\
\hline Technological infrastructure & 200 & 93,0 & 15 & 7,00 \\
\hline The frequency of interaction & 188 & 87,4 & 27 & 12,6 \\
\hline The type of the content & 133 & 61,9 & 82 & 38,1 \\
\hline Educational level & 132 & 61,4 & 83 & 38,6 \\
\hline Density of the content & 125 & 58,1 & 90 & 41,9 \\
\hline Educational strategy, method, techniques & 121 & 56,3 & 94 & 43,7 \\
\hline Assessment \&evaluation methods & 106 & 49,3 & 109 & 50,7 \\
\hline Students' computer / internet usage levels & 102 & 47,4 & 113 & 52,6 \\
\hline Course duration / length & 94 & 43,7 & 121 & 56,3 \\
\hline
\end{tabular}

The Table 3 shows that the "technological infrastructure" was taken into consideration by $\% 93$ of the participants while determining the number of students for virtual classrooms. Also $\% 87,4$ of the participants considers "frequency of interaction" as a determinative feature. The difference between the distribution of "yes" and "no" responses related to "technological infrastructure" and "frequency of interaction" is remarkable. This can interpreted as the opinions of the participants related to these statements are quite clear. In another words, "technological infrastructure" and "frequency of interaction" are the most determinative features about number of students in virtual classes.

These features are followed by "the type of the content" (61,9\%), "educational level" $(61,4 \%)$, "density of the content" $(58,1 \%)$ and "educational strategy, method, techniques" (56,3\%). Among all the features the percentage of "course duration/length" is the lowest. So it can be said that the majority of participants mostly pay attention to technological issues like infrastructure and the frequency of interaction than the educational issues.

P2 and P7 as the participants of focus group also emphasize "technological infrastructure", "students' computer/internet usage levels" and "intensity of interaction" about the features considered in determining the number of students: 
(P2) "If the hardware and infrastructure is not appropriate for the virtual class, the system may crash. Also, I think students' needs and internet/ computer usage levels should be taken into consideration"

(P7) "If there will be intensive interaction, the number of students must be less. But if the student will be passive or the information will be transferred unilaterally, the number of students can be up to 30. So the frequency of interaction is important. Factors affecting the number of students can be discussed under two categories like the technical specifications and educational content related subjects."

As noted by Karaçalı [13], when the number of students is kept less, teaching methods can diversify, student-faculty interaction increases, student development and control become easier, also effective classroom management can be possible. In parallel, Schlusmans et al [17] emphasize that group size is an effective issue for virtual classroom management and stated that instructors should pay attention to have manageable number of students.

Another feature that is undertaken as part of the physical layout of virtual classrooms is "noise". The distribution of the responses related to features that can be regarded as the noise components in virtual classes is given in Table 3 .

\section{Table 4. Noise Elements}

\begin{tabular}{|c|c|c|c|c|}
\hline & \multicolumn{2}{|c|}{$\mathbf{Y}$} & \multicolumn{2}{|c|}{$\mathbf{N}$} \\
\hline & $\mathbf{f}$ & $\%$ & $\mathbf{f}$ & $\%$ \\
\hline Microphone problems & 197 & 91,6 & 18 & 8,4 \\
\hline Internet connection problems & 184 & 85,6 & 31 & 14,4 \\
\hline Too high/low voice & 183 & 85,1 & 32 & 14,9 \\
\hline $\begin{array}{l}\text { Presence of the instructor in a crowded } \\
\text { office during the course }\end{array}$ & 172 & 80,0 & 43 & 20,0 \\
\hline $\begin{array}{l}\text { Instructors' inability to answer all } \\
\text { messages due to the intensity of } \\
\text { written messages }\end{array}$ & 163 & 75,8 & 52 & 24,2 \\
\hline Old writings remain on the screen & 116 & 54,0 & 99 & 46,0 \\
\hline Students' lack of hardware & 112 & 52,1 & 103 & 47,9 \\
\hline Students' late log in & 102 & 47,4 & 113 & 52,6 \\
\hline Using different colours for messages & 41 & 19,1 & 174 & 80,9 \\
\hline
\end{tabular}

Table 4 shows most of the participants think that technical features such as crackling sound $(91.6 \%)$ too high or low voice $(85.1 \%)$ and internet connection problems $(85.6 \%)$ are noise elements which come to the fore in virtual classes. On the other hand, "presence of the instructor in a crowded office during the course" with $80 \%$ and "Instructors' inability to answer all messages due to the intensity of written messages" with $75,8 \%$ are the other noise element that most of the participants agreed on. Although $80,9 \%$ of the participants think that "using different colors for messages" isn't a noise element; in contrast P4 believes it is. Opinions of P4 and P7 about the noise elements in virtual classes are as follows:

(P4) "I think different text colors for students and educators or for each student generate noise visually. In fact the distinctive feature in virtual platform is name. But if you want to be more distinctive, personal photographs can be used."

(P7) "One of the common issues we face with is buzzing speaker of the speaking students. In order to prevent this, certain standards need to be implemented about using the hardware. Some warnings must be done like "use your headphones to listen and talk to the microphone. Don't use the internal speaker of your computer"

Lack of technical skills and qualifications of the teaching staff can cause high levels of anxiety about using technology. Therefore they can consider the technical problems as important noise elements in virtual classes. The high participation degree about technical problems can be associated with this situation.

Additionally, intensity of written message is also one of the most important noise elements mentioned by participants. Because of written texts are the main communication tool in virtual classes in terms of student-student and student-instructor interaction, the problems related with the intensity of written messages could have been handled as one of the noise elements of virtual classes by the participants.

Table 4 also shows that participants are unstable about the problems resulting from the students such as late $\log$ in or lack of hardware. They are undecided about whether to accept these problems as a noise factor. According to a widely accepted view in distance education, students are responsible for their own learning process. Because of this widely accepted view they could have been unstable about the problems resulting from the students. On the other hand, instructors have limited opportunities to intervene the problems like students' lack of hardware. This may also be considered as an issue of staying undecided about whether to accept these problems as a noise factor.

Another feature associated with the physical layout of virtual classrooms is design elements. As mentioned before, placement arrangements" and 
elements like "heat, light, color and cleanliness" are considered within the context of instructional design in virtual classes. The participants were asked to mark one of the following choices for each statement related to the design elements of virtual classes which they thought it fit concerning the frequency of the their usage: "(5) Always, (4) Frequently, (3) Seldom, (2) Rarely, (1) Never. The distribution of the responses about the design elements are given in Table 4.

Table 5. Design Elements

\begin{tabular}{|c|c|c|c|c|c|c|}
\hline & $\overbrace{\bar{E}}^{\infty}$ & & 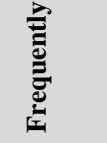 & 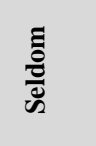 & 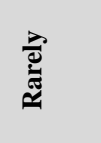 & 峁 \\
\hline & f & $\%$ & f $\%$ & F \% & f $\%$ & F \% \\
\hline $\begin{array}{l}\text { Using compelling } \\
\text { graphics }\end{array}$ & 56 & 26,0 & 9142,3 & 4520,9 & 167,4 & $7 \quad 3,3$ \\
\hline $\begin{array}{l}\text { Using motion } \\
\text { elements in } \\
\text { moderation }\end{array}$ & 34 & 15,8 & $\begin{array}{ll}60 & 27,9\end{array}$ & 4721,9 & 4922,8 & 2511,6 \\
\hline $\begin{array}{l}\text { Not using redundant } \\
\text { information within } \\
\text { the content }\end{array}$ & 105 & 48,8 & 9544,2 & 125,6 & 10,5 & 20,9 \\
\hline $\begin{array}{l}\text { Using clear } \\
\text { expressions }\end{array}$ & 144 & 67,0 & 6530,2 & $6 \quad 2,8$ & - & $-\quad-$ \\
\hline $\begin{array}{l}\text { Using appropriate } \\
\text { font within the } \\
\text { materials }\end{array}$ & 69 & 32,1 & $\begin{array}{ll}60 & 27,9\end{array}$ & 3014,0 & 4721,9 & $9 \quad 4,2$ \\
\hline $\begin{array}{l}\text { Using appropriate } \\
\text { line/ paragraph } \\
\text { spacing }\end{array}$ & 63 & 29,3 & $\begin{array}{ll}60 & 27,9\end{array}$ & 198,8 & 4822,3 & 2511,6 \\
\hline $\begin{array}{l}\text { Studying on a } \\
\text { single window to } \\
\text { keep concentration }\end{array}$ & 55 & 25,6 & 6228,8 & 4721,9 & 3315,3 & 188,4 \\
\hline
\end{tabular}

Table 5 shows that, "using concise statements" has the highest percentage among all categories. When the responses are classified as always and frequently, the second highest percentage is belongs to "not using redundant information within the content" with $93 \%$.

Frequencies in Table 5 show that all the elements taken into account in general. "Not using redundant information within the content" and "Using clear expressions" are two of the most important and commonly used statements according to the participants. In this context, it can be said that instructors care more about the content design elements than the visual design elements.

Opinions of P3 about adapting physical layout features like heat, light and cleaning to virtual classes as design elements are stated as below:

(P3) "Heat, light and cleaning features can be associated with interface, contrast, colors, display settings and content updating in virtual classes. Also, simple design and feeling comfortable are important issues related to these features."

Faculty members see themselves as subject and content experts. Not having clear job descriptions within the virtual classrooms can be considered to be effective in this case. P1 and P3 stated their opinions related to these design elements as below:

(P1) "Our opinions about the virtual classroom design are not asked. Also there is no systematic training or notification for teaching staff. We use a pre-designed program. Experienced friends are trying to help others. Problems that cannot be solved in this way are asked to the technical support. In addition, there is no clear definition about who is responsible for what. This can cause confusions and problems in the process. On the other hand, we need better equipped computers, but it isn't taken into account, too."

(P3) "Administrators assume that we qualified enough to conduct lessons in a virtual environment. Also there is a gap between the technical and teaching staff. Defining the responsibilities for each team member is important in the management process which require co-operation."

When the correlation between the opinions and frequencies in Table 5 is considered, the common views about the priority of technical design elements could be associated with lack of enough technical skills of instructors, not having an inservice training or even if they have in-service training not giving detailed explanations about visual design elements. So they may concentrate on technical/virtual design elements than educational content design issues.

\section{Results and Suggestions}

It is thought that informing instructors about differing aspects of classroom management for virtual classrooms by in-service training will be helpful for more effective applications. Issues that are thought to be explained within the in-service trainings, especially related with the physical layout of the virtual classes, can be stated as below:

- The impact and importance of the students' computer/internet usage levels, course duration/length, technological infrastructure and frequency of interaction on determining the number of students 
- The impact of noise components and technical problems on teaching-learning process

- The effects of visual design elements on the teaching-learning process

Also these training programs can include physical layout but also plan \& program activities, behavior management, time management, and opportunities for interaction. On the other hand, establishing of special units for virtual classes within the faculties/universities to provide more professional trainings is thinkable.

It should be noted that managing virtual classrooms isn't only a technical issue. So the trainers must be experts of both technological and pedagogical features.

Additionally, determining the educational needs of students for effective virtual classrooms can be considered as another research subject. As well as examining the contents of existing in-service trainings and investigating the adequacy of them is also important.

\section{Conclusion}

According to the results of this study, it can be said that the ideal number of students in virtual classes should be up to 15 . Also the most determinative features about number of students in virtual classes are determined as "technological infrastructure" and "frequency of interaction".

When the noise factors in virtual classes are considered it is seen that technical features such as crackling sound, too high or low voice and Internet connection problems come to the fore.

On the other hand, the results related to design elements show that instructors care more about the content design elements than the visual design elements.

Finally, based on the results, the physical layout of virtual classes has some special qualifications when compared to the face-to-face classes. In this context, it is important to define these qualifications in detail. Also it is necessary to inform the instructors to make virtual classes more effective.

\section{Acknowledgements}

In this study a part of the findings are given from the researcher's dissertation titled as "Identifying the Educational Needs of Instructors Commissioned in Virtual Classroom Management" (Advisor: E. Agaoglu)

\section{References}

[1] Taşpınar, M. ve Gümüş, Ç. (2004) 'Öğrenmeyi Öğrenme Kapsamında İnternet Kafelerin Eğitsel Bir Araç Olarak Kullanımı' İnönü Üniversitesi XIII. Ulusal Eğitim Bilimleri Kurultay1; http://www.kocaeli.pol.tr/ bilim/7-renmeyi\%20ogrenme_Bilimsel_Faaliyetler.doc (29.03.2013)

[2] Ke, F. (2004) 'Forming Virtual Learning Community within Online Course: Students' Perspectives' Association for Educational Communications and Technology, Chicago: IL.

[3] Noden, H. and Moss, B. (1993) 'Virtual Schools: Reading and Writing', The Reading Teacher, 47(2), 166168.

[4] Rutkowski, K. (1999) 'Virtual Schools: Charting New Frontier. Multimedia Schools' MultiMedia Schools, 6(1), 1999, pp. $74-79$.

[5] Ağaoğlu, E. (2012) 'Sınıf Yönetimiyle İlgili Genel Olgular'. Sinıf Yönetimi (Ed: Z. Kaya). Ankara: Pegem A Yayınc1lik, pp. 1-42

[6] Demirtaş, H. (2005) 'Sınıf Yönetiminin Temelleri' Etkili Sınıf Yönetimi (Ed: H. Kıran). Ankara: An1 Yayınc1lk, pp.1-34.

[7] Tutkun, Ö. F. (2012) 'Sınıf Düzeni' Sinıf Yönetimi (Ed: Z. Kaya). Ankara: Pegem A Yayıncılık, pp.237-264.

[8] Aydın, A. (2000) 'Sınıf Yönetimi' İstanbul: Alfa Yayınları

[9] Celep, C. (2008) 'Sınıf Yönetiminde Kuram ve Uygulama' Ankara: Pegem Akademi

[10] Işık, H. (2007) 'Öğrenme Ortamlarının Fiziksel Düzeni” Sinıf Yönetimi (Ed: M. Şişman ve S. Turan). Ankara: Pegem A Yayıncılık, pp.27-39

[11] Gündüz, H. B. (2004) 'Eğitim Okul ve Sınıf Yönetimi” Sınıf Yönetimi (Ed: S. Erçetin ve Ç. Özdemir). Ankara: Asil Yayın Dagitım, pp.3-32

[12] Tanilli, S. (2009) 'Nas1l Bir Eğitim İstiyoruz?' İstanbul: Cumhuriyet Kitapları.

[13] Karaçalı, A. (2006) 'Sınıf Yönetimini Etkileyen Fiziksel Değişkenlerin Değerlendirilmesi' Gazi Üniversitesi Kırşehir Eğitim Fakültesi Dergisi, 7(1), pp.145-155

[14] McBrien, J. L., Jones, P. and Cheng, R. (2009) 'Virtual Spaces: Employing a Synchronous Online Classroom to Facilitate Student Engagement in Online Learning' International Review of Research in Open and Distance Learning, 10(3), pp.1-17. 
[15] Dessoff, A. (2009) 'The Rise of Virtual Teacher' District Administration, February.

[16] Proserpio, L. and Gioia, D. A. (2007) 'Teaching the Virtual Generation' Academy of Management Learning \& Education, 6(1), 2007, pp.69-80.

[17] Schlusmans, K., Giesbertz, W., Rusman, E. and Spoelstra, H. (2009) 'The Introduction Of A Virtual Classroom Instrument At The Open University Of The Netherlands', in the Proceedings of the 23rd ICDE World Conference on Open Learning and Distance Education including the 2009 EADTU Annual Conference, Maastricht, Hollanda 